\title{
Hybrid Effect of Nano Silica and Metakaolin on Mechanical Properties of Cement Mortar
}

\author{
Taher A. Tawfik \\ Department of Construction and Building \\ Higher Institute of Engineering, \\ Giza, Egypt \\ Khaled Aly Metwally \\ Department of Construction and building \\ Higher Institute of Engineering, \\ Giza, Egypt
}

\author{
W. Zaki \\ Department of civil engineering \\ Faculty of engineering, \\ Beni-Suef University, Egypt \\ A. Serag Faried \\ Department of Civil Engineering \\ Faculty of Engineering, Fayoum University, \\ Fayoum, Egypt
}

\begin{abstract}
In this work, metakaolin (MK) and nano silica have been used as cementitious matrices in micro and nano scale. The mechanical behavior of these Concrete is widely used construction material for the development of built environment which consumes huge amount of cement, around 4.3 billion metric ton all over the world. Reinforced concrete construction exposed to harsh environment such as chloride bound air causes deterioration in concrete through its pore structure by corroding the steel bar. The use of pozzolanic material i.e. metakaolin (MK), and nano silica (NS) can be used as partially cement replacing material which not only reduces the pores in cement mortar but improves the mechanical properties and microstructure of cement mortar. This paper discuss effect of using MK and NS on cement mortar properties and incorporation of MK and NS in concrete and their effects on concrete mechanical properties. However, the research work provides an extended approach to evaluate combine effect using MK, and NS and to produce a cement mortar with more refined pore structure.
\end{abstract}

Keywords: Metakoalin, nano silica, compressive strength, flexural strength

\section{INTRODUCTION}

The mechanical behavior of concrete materials depends on structural elements and phenomena that occur in a micro and a nano scale. As a result, nanotechnology can modify the molecular structure of concrete which leads to improvement in the material's bulk properties. Nanotechnology can also improve the mechanical performance, volume stability, durability, and sustainability of concrete. The revolutionary effects accompanying nanotechnology allows the development of cost-effective, high-performance, and long-lasting products of cement and concrete which can lead to unprecedented uses of concrete materials. One of the most desired properties of nanomaterials in the construction sector is their capability to confer a mechanical reinforcement to cement based structural materials. When using nanomaterials three main advantages are considered. The first advantage is the production of high-strength concrete for specific application. The second advantage is to reduce the amount of cement needed in concrete in order to obtain similar strengths and decreasing the cost and the environmental impact of construction materials. The third advantage is reducing the construction periods as nanomaterials can produces high-strength concrete with less curing time [1]. The performance of these cementitious based materials is strongly dependent on nano-sized solid particles, such as particles of calcium-silicate-hydrates $(\mathrm{C}-\mathrm{S}-\mathrm{H})$, or nanosized porosity at the interfacial transition zone between cement and aggregate particles. Typical properties affected by nano-sized particles or voids are strength, durability, shrinkage and steel-bond [2]. Nano-particles of $\mathrm{SiO} 2(\mathrm{nS})$ can fill the spaces between particles of gel of $\mathrm{C}-\mathrm{S}-\mathrm{H}$, acting as a nano-filler. Furthermore, by the pozzolanic reaction with calcium hydroxide, the amount of $\mathrm{C}-\mathrm{S}-\mathrm{H}$ increases, resulting a higher densification of the matrix, which improves the strength and durability of the material. Previous research [3-9] indicates that the inclusion of nanoparticles modifies fresh and hardened state properties, even when compared with conventional mineral additions. Colloidal particles of amorphous silica appear to considerably impact the process of C3S hydration [5]. Nano-silica decreased the setting time of mortar when compared compared with silica fume (SF) [6] and reduced bleeding water and segregation, while improving the cohesiveness of the mixtures in the fresh state [7]. When combined with ultra-fine fly ash it assures better performance than that achieved by the use of silica fume alone [3]. Besides, the compressive strength of mortar or concrete with silica fume is improved when compared with formulations without addition [7-9].

Metakaolin has been recently introduced as a highly active and effective pozzolan for the partial replacement of cement in concrete. It is an ultrafine material produced by the dehydroxylation of a kaolin precursor upon heating in the temperature range of $700-800 \circ \mathrm{C}$ [10]. Metakaolin is a silica-based product that, on reaction with $\mathrm{Ca}(\mathrm{OH})_{2}$, produces $\mathrm{CSH}$ gel at ambient temperature. Metakaolin also contains alumina that reacts with $\mathrm{CH}$ to produce additional alumina-containing phases, including C4AH13, C2ASH8, and C3AH6 [11,12]. Research results have shown that the incorporation of metakaolin in concrete significantly enhances early strength [13]. Metakaolin increases resistance of concrete to alkali-silica reaction [14], and its 
effect on sulfate resistance increases systematically with increasing the replacement ratio of cement by metakaolin [15]. Energy absorption or toughness of high-performance steel-fiber-reinforced concrete is increase with the introduction of high-reactivity metakaolin into the mix. Therefore, for applications where both enhanced durability and high toughness are required, the use of high-reactivity metakaolin concrete may be advantageous [16]. However, other research has also shown that increasing replacement levels of metakaolin produce increasing water demand, although this can be adjusted by adding a water reducer to maintain the workability or flow properties [17].

This paper reports the effects of nano-sized amorphous silica and metakaolin on mechanical properties of cement mortars.

\section{MATERIALS}

\section{A. Cement}

The cement used in this study is the ASTM type (I) Ordinary Portland cement (OPC) produced by Misr Beni Suef company (Beni Suef city, Egypt). Some tests are conducted on a sample of cement to ensure quality testing specific weight, fineness, soundness of cement, initial and final setting time. The physical properties of the cement sample as a result of these tests are given in Table I.

Table I: Physical properties of cement

\begin{tabular}{|c|c|c|}
\hline No. & Property & Result \\
\hline 1 & Specific gravity & 3.15 \\
\hline 2 & Fineness & $2700 \mathrm{~cm}^{2} / \mathrm{g}$ \\
\hline 3 & Initial setting time & 85 minutes \\
\hline 4 & Final setting time & 180 minutes \\
\hline 5 & Compressive strength & $\mathrm{Kg} / \mathrm{cm}^{2}$ \\
\hline a) & 3 days & 202 \\
\hline b) & 7 days & 308 \\
\hline c) & 28 days & 438 \\
\hline 6 & Soundness & $1 \mathrm{~mm}$ \\
\hline
\end{tabular}

\section{B. Fine aggregates}

Sand was used in this research. Sand was tested according to ASTM C128. The physical property of sand is shown in table II.

Table II: Standard sand physical properties

\begin{tabular}{|c|c|c|}
\hline No & Property & Result \\
\hline $\mathbf{1}$ & Specific & 2.65 \\
\hline $\mathbf{2}$ & Bulk density & $1650 \mathrm{~kg} / \mathrm{m}^{3}$ \\
\hline $\mathbf{3}$ & Grading & Percent \\
\hline $\mathbf{4}$ & $\begin{array}{c}\text { Percent of Clay } \\
\text { and other Fine }\end{array}$ & $0 \%$ \\
\hline
\end{tabular}

\section{C. metakaolin}

Metakaolin had $99.9 \%$ particles $<16 \mu \mathrm{m}$ with a mean particle size of about $3 \mu \mathrm{m}$ Table III. The typical chemical composition is given in Table IV.
Table III: Physical properties of metakaolin

\begin{tabular}{|l|c|}
\hline Property & Value \\
\hline Specific gravity & 2.57 \\
\hline Bulk density (g/cm3) & 0.4 \\
\hline Physical form & Powder \\
\hline GE Brightness & 80 \\
\hline Color & Off- White \\
\hline
\end{tabular}

Table IV: Chemical analysis of metakaolin

\begin{tabular}{|l|c|}
\hline content & \% weight \\
\hline $\mathrm{SiO}_{2}$ & 51.52 \\
\hline $\mathrm{TiO}_{2}$ & 51.52 \\
\hline $\mathrm{Al}_{2} \mathrm{O}_{3}$ & 40.18 \\
\hline $\mathrm{Fe}_{2} \mathrm{O}_{3}$ & 1.23 \\
\hline $\mathrm{MgO}$ & 0.12 \\
\hline $\mathrm{CaO}$ & 2.0 \\
\hline $\mathrm{Na} 2 \mathrm{O}$ & 0.08 \\
\hline $\mathrm{K}_{2} \mathrm{O}$ & 0.53 \\
\hline $\mathrm{SO}$ & 0.0 \\
\hline $\mathrm{LOI}$ & 12.01 \\
\hline
\end{tabular}

\section{Nano- silica}

The nano silica used in this research was prepared at the Beni Suef central laboratories. Table V and VI respectively; illustrate physical and chemical of Nano-silica

Table V: Nano-silica physical properties

\begin{tabular}{|l|c|}
\hline Property & result \\
\hline Particle size $(\mu \mathrm{m})$ & 7.00 \\
\hline Bulk density $\left(\mathrm{kg} / \mathrm{m}^{3}\right)$ & 345 \\
\hline Specific gravity & 2.15 \\
\hline Specific surface area $\left(\mathrm{m}^{2} / \mathrm{kg}\right)$ & $17.8 \times 10^{3}$ \\
\hline Color & Light gray \\
\hline
\end{tabular}

Table VI: chemical properties of nano-silica

\begin{tabular}{|l|c|}
\hline content & Content (\%) \\
\hline $\mathrm{SiO}_{2}$ & 99.65 \\
\hline $\mathrm{TiO}_{\mathbf{2}}$ & 0.02 \\
\hline $\mathrm{Al}_{\mathbf{2}} \mathbf{O}_{\mathbf{3}}$ & 0.01 \\
\hline $\mathrm{Fe}_{\mathbf{2}} \mathbf{O}_{\mathbf{3}}$ & 0.012 \\
\hline $\mathbf{M n O}$ & $<0.01$ \\
\hline $\mathbf{M g O}$ & $<0.01$ \\
\hline $\mathbf{C a O}$ & $<0.01$ \\
\hline $\mathbf{N a}_{2} \mathbf{O}$ & $<0.01$ \\
\hline $\mathrm{K}_{\mathbf{2}} \mathbf{O}$ & $<0.01$ \\
\hline $\mathbf{P}_{\mathbf{2}} \mathbf{O}_{\mathbf{5}} \mathrm{O}$ & $<0.01$ \\
\hline $\mathbf{L O I}$ & 0.25 \\
\hline
\end{tabular}

\section{E. Superplasticizer}

In this study the chemical admixture used as superplasticizer was high range water reducer of modified polycarboxylates. According to ASTM C494 (types F) was manufactured. The chemical admixture main concept Control the total Performance, whereas allows cement particles delayed absorption and distribute them. High range water reducer superplasticizers obtained a high quality concrete mix with increasing strength. Table VII shows Properties of the superplasticizer [18]. 
Table VII: Technical Data Properties of the superplasticizer

\begin{tabular}{|c|c|}
\hline Form & $\begin{array}{c}\text { Aqueous solution of modified } \\
\text { polycarboxylates }\end{array}$ \\
\hline Appearance & Brown liquid \\
\hline Density & $1.185 \mathrm{~kg} /$ liter \\
\hline $\mathrm{pH}$ value & $4.5-4.9$ \\
\hline
\end{tabular}

\section{MORTAR MIXING}

Fresh mortars were prepared with binder/aggregate weight ratio (B/A) of $1: 2$ and water/binder (W/B) ratio of 0.35 . The cement paste was prepared with the same W/B ratio. Mortars and paste were produced with0\%, 10\%, 20\% and $30 \%$ metakaolin (first group) and second group constant percentage of metakaolin $(20 \mathrm{wt} \%)$ with different percentage of nanosilica $0 \%, 2 \%, 4 \%$ and $6 \% \mathrm{NS}$ in weight, replacing cement. The amount of SP was $1.5 \mathrm{wt} \%$ of the binder cement (first group) but in second group (cement plus NS). These compositions are shown in Table (VIII \& IX). The preparation of mortars involved: (a) weighing of the components, (b) mixing the solid components inside a plastic bag for 1 min, (c) adding NS and superplasticizer into water, (d) pouring the solid components into water and (e) mechanical mixing for 3.5 $\min$ at $60 \mathrm{rpm}$. The amount of water incorporated with $\mathrm{nS}$ was taken into account by reducing the nominal content of water added to the preparation of the mortar.

Table VIII: Mortar formulations

\begin{tabular}{|c|c|c|c|c|}
\hline $\begin{array}{c}\text { Mix } \\
\text { component }\end{array}$ & Cement & Sand & Water & SP \\
\hline Weight (g) & 250 & 500 & 87.5 & 3.75 \\
\hline
\end{tabular}

Table IX: Mix composition of the investigated mixes

\begin{tabular}{|c|c|c|c|c|c|}
\hline Group & $\begin{array}{c}\text { Mix } \\
\text { No. }\end{array}$ & Mix Notation & O.P.C & MK & NS \\
\hline \multirow{2}{*}{ A } & 1 & OPC & 100 & 0 & 0 \\
\hline \hline \multirow{2}{*}{ B } & 2 & $\mathrm{Mk}_{10}$ & 90 & 10 & 0 \\
\cline { 2 - 6 } & 3 & $\mathrm{MK}_{20}$ & 80 & 20 & 0 \\
\cline { 2 - 6 } & 4 & $\mathrm{MK}_{30}$ & 70 & 30 & 0 \\
\hline \hline \multirow{2}{*}{ C } & 6 & $\mathrm{MK}_{20} \mathrm{NS}_{2}$ & 78 & 20 & 2 \\
\cline { 2 - 6 } & 7 & $\mathrm{MK}_{20} \mathrm{NS}_{4}$ & 76 & 20 & 4 \\
\hline \hline $\begin{array}{l}\text { OPC : ordinary Portland cement } \\
\text { MK Metakaolin } \\
\text { NS : Nano-silica }\end{array}$ & $\mathrm{MK}_{20} \mathrm{NS}_{6}$ & 72 & 20 & 6 \\
\hline
\end{tabular}

\section{TESTING PROCEDURES}

The mortar pastes were molded into $7.07 \mathrm{~cm}$ cubes for compressive strength. The molds were vibrated for $1 \mathrm{~min}$ to remove any air bubbles. The samples were kept in molds at $100 \%$ relative humidity for $24 \mathrm{~h}$, and then cured in water for 28 days. The hardened cement mortar was removed from water before mechanical tests. The compressive strength was performed on wetted specimens. The crushed samples resulted from compressive strength tests were grounded to be used for thermal and microstructure analysis. The evaporable water of the hydrated crushed samples was removed using the method described elsewhere [19].

\section{TESTING}

\section{A. Compressive strength}

The compressive strength tests were performed on a Toni Tech machine using $50 \mathrm{~mm}$ cube samples. Three samples per batch were tested, and the average strength value was reported. The loading rate on the cubes was $35 \mathrm{~N} / \mathrm{mm}^{2} / \mathrm{min}$.

\section{B. Flexural strength}

Toni Tech machine was used to perform the flexural strength tests and using 40x40x160 mm prism samples. Three samples per batch were tested, and the average strength value was reported.

\section{RESULTS AND DISCUSSION}

\section{A. compressive strength}

Compressive strength of blended mortar containing different percentage of MK and optimum Mk (20\%) with different NS (2, 4 and 6wt., \%) at 3, 7, 28 and 90 day of hydration are given in Table (X \& XI). the development of the mean values of compressive strength of blended mortar containing different percentage of $\mathrm{MK}$ and optimum $\mathrm{Mk}$ (wt.,\%) incorporated different NS shows in Fig. (1\&2). Basically, the compressive strength increased with the increase of MK until it reaches an optimal amount of $20 \%$ and then started to drop that Fig. 1 whilst Fig. 2 show (20\% MK incorporated 4\% NS) is the optimum percentage. Evidently, the replacement of OPC by $20 \%$ MK in blended mortar increases the compressive strength by $19 \%$ compare 
to control mix. The enhancement of compressive strengths of hardened cement mortar due to the addition of MK can be explained by two mechanisms. The first strengthening mechanism was the packing effect of MK acted as filler to fill into the interstitial spaces inside the skeleton of hardened microstructure of cement mortar which leads to increments in strength and density. The second strengthening mechanism was the pozzolanic effect that combines glass-like silicon and alumina elements in MK with the lime elements of calcium oxide and hydroxide in cement to add the bonding strength and solid volume, resulting in higher compressive strength of hardened cement mortar [1]. Most pozzolanic reaction between the calcium hydroxide and amorphous NMK (silicon and alumina dioxide) normally reacts slowly during a prolonged period of moist curing. Since the platelet particles of NMK have an average dimensions of (200X $100 \mathrm{X} 20 \mathrm{~nm}$ ) which is about 1000 times finer than average cement particle of $20 \mathrm{~lm}$ resulting in an extremely large surface area, the NMK reacts very rapidly with the calcium hydroxide to form calcium silicate in an alkaline environment such as the pore solution of fresh Portland cement paste. Badogiannis et al. [20] investigated the effect of metakaolin on the compressive strength of concrete. Poor Greek kaolin (C) was thermally treated and the produced metakaolin (MK) was superfine ground. In addition, a commercial metakaolin (MKC) of high purity was used. In concrete mixtures, metakaolin replaced either cement or sand in percentages of $10 \%$ or $20 \%$ by weight of the control cement content.

Table X: Compressive strengths $(\mathrm{Kg} / \mathrm{Cm} 2)$ of OPC and modified cement mortars with metakaolin at different curing times $(3,7,28$ and 90 day)

\begin{tabular}{|c|c|c|c|c|}
\cline { 2 - 5 } \multicolumn{1}{c|}{} & \multicolumn{4}{c|}{ Curing time days } \\
\hline Mix. notation & $\mathbf{3}$ & $\mathbf{7}$ & $\mathbf{2 8}$ & $\mathbf{9 0}$ \\
\hline OPC & 184 & 201 & 248 & 325 \\
\hline MK $_{\mathbf{1 0}}$ & 194 & 204 & 257 & 340 \\
\hline MK $_{\mathbf{2 0}}$ & 235 & 246 & 306 & 385 \\
\hline MK $_{\mathbf{3 0}}$ & 219 & 238 & 272 & 364 \\
\hline
\end{tabular}

Table XI: Compressive strength $(\mathrm{Kg} / \mathrm{Cm} 2)$ of OPC and modified cement mortars

with metakaolin and Nano-silica as a function curing time $(3,7,28$ and 90 days $)$

\begin{tabular}{|c|c|c|c|c|}
\cline { 2 - 5 } \multicolumn{1}{c|}{} & \multicolumn{4}{c|}{ Curing time days } \\
\hline $\begin{array}{c}\text { Mix. } \\
\text { notation }\end{array}$ & $\mathbf{3}$ & $\mathbf{7}$ & $\mathbf{2 8}$ & $\mathbf{9 0}$ \\
\hline $\mathbf{O P C}$ & 184 & 201 & 248 & 325 \\
\hline $\mathbf{M K}_{\mathbf{2 0}} \mathbf{N S}_{\mathbf{2}}$ & 249 & 261 & 322 & 402 \\
\hline $\mathbf{M K}_{\mathbf{2 0}} \mathbf{N S}_{\mathbf{4}}$ & 281 & 309 & 397 & 494 \\
\hline $\mathbf{M K}_{\mathbf{2 0}} \mathbf{N S}_{\mathbf{6}}$ & 275 & 299 & 389 & 482 \\
\hline
\end{tabular}

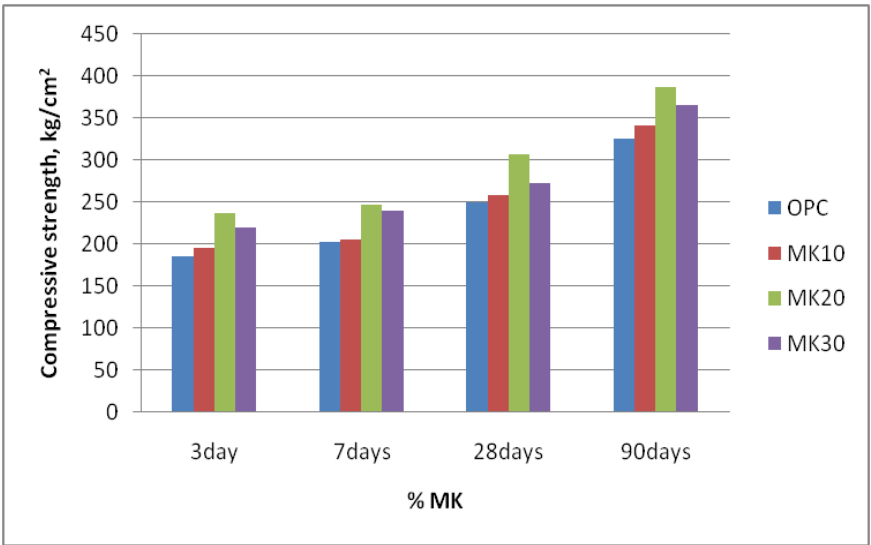

Fig.1: Relationship between the compressive strength of concrete after 3,7,28 and 90 days and added MK with different ratios.

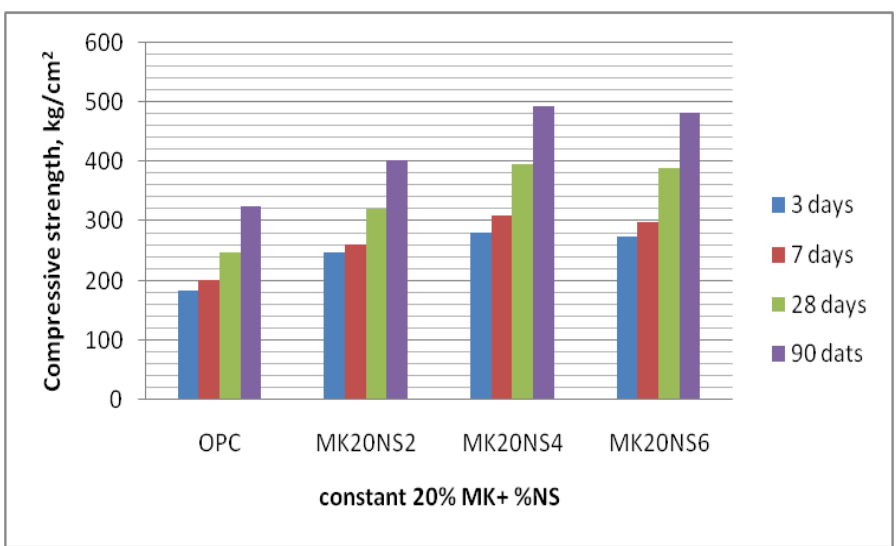

Fig.2: Relationship between the compressive strength of concrete after 3, 7, 28 and 90 days and added $20 \% \mathrm{MK}+$ with different ratios of NS.

\section{B. Flexural strength}

The flexural strength of cement mortar incorporating ( 0 , 10,20 , and $30 \%$ ) metakaolin as partial replacement of cement results are given in Table XII. Flexural strength of cement mortar increased systematically with increasing metakaolin replacement. Metakaolin replacement of $10 \%$ had a good effect on the bending strength of the concrete. At 20 and $30 \%$ replacement, the 90-day bending strength increased by $16 \%$ and $10 \%$, respectively. Table XIII and Fig. 4 are shown the (20\% MK incorporated $4 \%$ NS) is the best ratio after that flexural strength declined. Evidently, the replacement of OPC by $20 \% \mathrm{MK}$ and $(20 \% \mathrm{MK}+4 \% \mathrm{NS})$ in blended mortar increases the compressive strength by $16 \%$ and $10 \%$ compare to control mix. Again, In early ages $\mathrm{Ca}(\mathrm{OH})_{2}$ consumption is the main reason of increasing split tensile strength in mixtures contain nano- particles.

Table XII: Flexural strength $\left(\mathrm{Kg} / \mathrm{Cm}^{2}\right)$ of OPC and blended cement mortars containing metalaolin at different curing ages $(3,7,28$ and 90 days)

\begin{tabular}{|c|c|c|c|c|}
\cline { 2 - 5 } \multicolumn{1}{c|}{} & \multicolumn{4}{c|}{ Curing time days } \\
\hline Mix. notation & $\mathbf{3}$ & $\mathbf{7}$ & $\mathbf{2 8}$ & $\mathbf{9 0}$ \\
\hline OPC & 135 & 140 & 185 & 230 \\
\hline MK $_{\mathbf{1 0}}$ & 160 & 170 & 205 & 245 \\
\hline $\mathbf{M K}_{\mathbf{2 0}}$ & 175 & 185 & 215 & 265 \\
\hline $\mathbf{M K}_{\mathbf{3 0}}$ & 148 & 164 & 196 & 253 \\
\hline
\end{tabular}


Table XIII: Flexural strength $\left(\mathrm{Kg} / \mathrm{Cm}^{2}\right)$ of OPC and cement mortars modified with $20 \%$ metakaolin and Nano-silica at $3,7,28$ and 90 day.

\begin{tabular}{|c|c|c|c|c|}
\cline { 2 - 5 } \multicolumn{1}{c|}{} & \multicolumn{4}{c|}{ Curing time days } \\
\hline Mix. notation & $\mathbf{3}$ & $\mathbf{7}$ & $\mathbf{2 8}$ & $\mathbf{9 0}$ \\
\hline $\mathbf{O P C}$ & 135 & 140 & 15 & 230 \\
\hline $\mathbf{M K}_{\mathbf{2 0}} \mathbf{N S}_{\mathbf{2}}$ & 185 & 190 & 219 & 275 \\
\hline $\mathbf{M K}_{\mathbf{2 0}} \mathbf{N S}_{\mathbf{4}}$ & 195 & 205 & 230 & 285 \\
\hline $\mathbf{M K}_{\mathbf{2 0}} \mathbf{N S}_{\mathbf{6}}$ & 198 & 210 & 235 & 286 \\
\hline
\end{tabular}

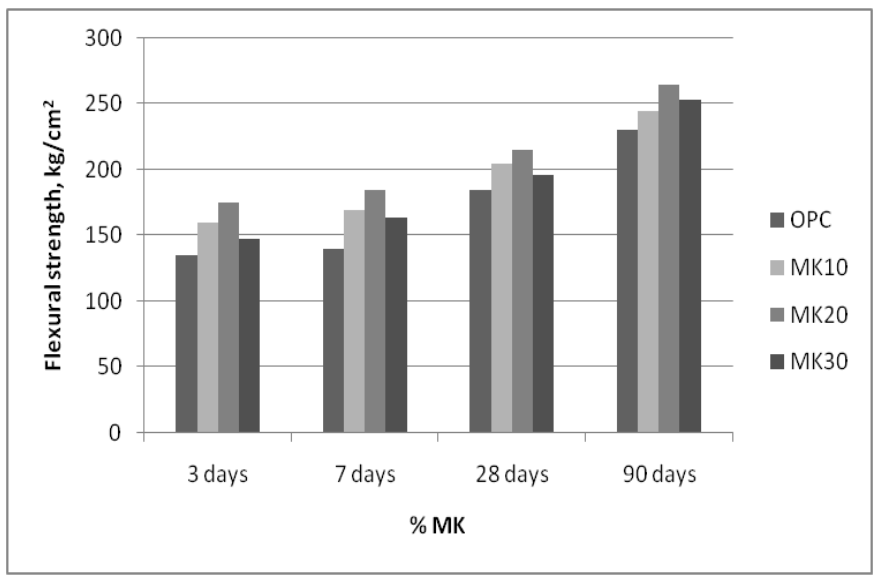

Fig.3: Relationship between the flexural strength of concrete after3, 7, 28 and 90 days and added MK with different ratios

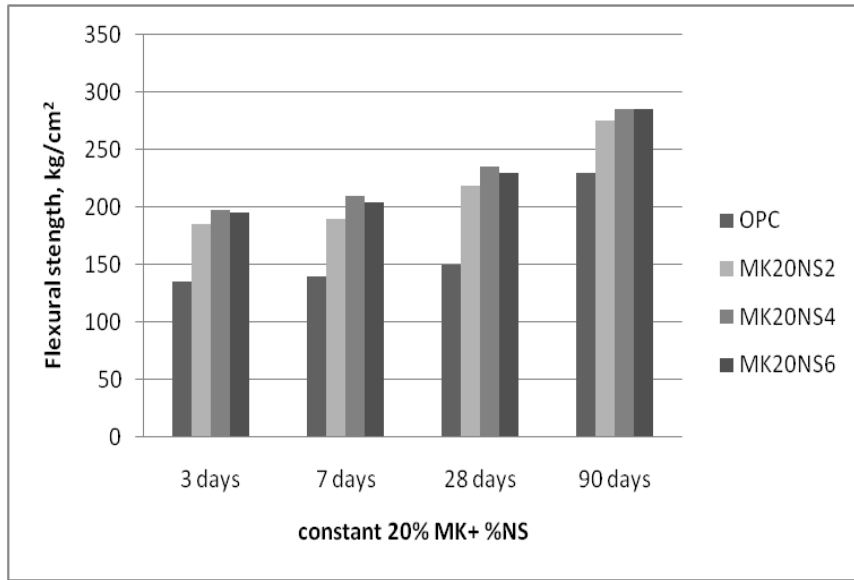

Fig.4: Relationship between the flexural strength of concrete after 3, 7, 28 and 90 days and added $20 \% \mathrm{MK}+$ with different ratios of NS

\section{CONCLUSIONS}

The following conclusions may be drawn from the obtained experimental data

1- Replacement of OPC by $20 \%$ exfoliated MK in cement mortar increases compressive strength by $19 \%$ compare to control mix.

2- Replacement of OPC by $20 \%$ exfoliated MK in cement mortar increases flexural strength by $16 \%$ compare to control mix.

3- The addition of NS (up to $4 \%$ ) to $20 \% \mathrm{MK}$ cement mortar improves the compressive strength of the composites. The improvement was $29 \%$ higher than blended mortar containing $20 \%$ NMK but the addition of (6\% NS with $20 \% \mathrm{MK}$ ) leads to decreases the compressive strength..

\section{REFERENCES}

[1] M.S. Morsy, S.H. Alsayed, M. Aqel, " Hybrid effect of carbon nanotube and nano-clay on physico-mechanical properties of cement mortar", Construction and Building Materials 25 (2011) $145-149$.

[2] [4] Collepardi S, Borsoi A, Ogoumah Olagot JJ, Troli R, Collepardi M, Cursio AQ. Influence of nano-sized mineral additions on performance of SCC. In: Proceedings of the 6th international congress, global construction, ultimate concrete opportunities, Dundee, UK; 5-7 July 2005.

[3] Older I. Lea's chemistry of cement and concrete. 4th ed. London: Arnold; 1998.

[4] Björnström J, Martinelli A, Matic A, Börjesson L, Panas I. Accelerating effects of colloidal nano-silica for beneficial calcium-silicate-hydrate formation in cement. Chem Phys Lett 2004:392(1-3):242-8

[5] Qing Y, Zenan Z, Deyu K, Rongshen C. Influence of nano-SiO2 addition on properties of hardened cement paste as compared with silica fume. Constr Build Mater 2007;21(3):539-45.

[6] Collepardi M, Ogoumah Olagot JJ, Skarp U, Troli R. Influence of amorphous colloidal silica on the properties of self-compacting concretes. In: Proceedings of the international conference in concrete constructions - innovations and developments in concrete materials and constructions, Dundee, Scotland, UK; 9 11 September 2002. p. 473-83.

[7] Li H, Zhang M, Ou J. Abrasion resistance of concrete containing nano-particles for pavement. Wear 2006;260(11-12):1262-6.

[8] Jo BW, Kim CH, Tae G, Park JB. Characteristics of cement mortar with nano-SiO2 particles. Cement Concr Compos 2007;21(6):1351-5.

[9] Li G. Properties of high-volume fly ash concrete incorporating nano-SiO2. Cement Concr Res 2004;34(6):1043-9.

[10] Klimesch DS, Ray A. Autoclaved cement-quartz pastes with metakaolin additions. Adv Cem Based Mater 1998;7:109-18.

[11] Changling H, Osbaeck B, Makovicky E. Pozzolanic reaction of six principal clay minerals: activation reactivity assessments and technological effects. CemConcr Res 1995;25(8):1691-702.

[12] Zhang MH, Malhotra VM. Characteristics of a thermally activated aluminasilicate pozzolanic material and its use in concrete. Cem Concr Res 1995;25(8):1713-25.

[13] Wild S, Khatib JM, Jones A. Relative strength, pozzolanic activity and cement hydration in superplasticised metakaolin concrete. Cem Concr Res 1996;26(10):1537-44.

[14] Jones TR, Walters GV, Kostuch JA. Role of metakaolin in suppressing ASR in concrete containing reactive aggregate and exposed to saturated $\mathrm{NaCl}$ solution. In: Proc 9th int conf alkaliaggregate react concr, vol. 1; 1992. p. 485-96.

[15] Khatib J, Wild S. Sulfate resistance of metakaolin mortar. Cem Concr Res 1998;28(1):83-92.

[16] Dubey A, Banthia N. Influence of high-reactivity metakaolin and silica fume on the flexural toughness of high-performance steel fiber reinforced concrete. ACI Mater J 1998;95(3):284-92.

[17] Bai J, Wild S, Sabir BB, Kinuthia JM. Workability of concrete incorporating pulverized fuel ash and metakaolin. Mag Concr Res 1999;51(3): 207-16.

[18] Mohamed Amin , Khaled Abu el-hassan.," Effect of using different types of nano materials on mechanical properties of high strength concrete". Construction and Building Materials; Vol. 80 (2015), pp116-124.

[19] Henning O, El-Didamony H, Hanna KM, Wiss Z. Hochsch Archit. Banwes: Weimar; 1972.

[20] Badogiannis, E., Papadakis, V.G., Chaniotakis, E., Tsivilis, S., 2004. Exploitation of poor Greek kaolins: strength development of metakaolin concrete and evaluation by means of $\mathrm{k}$-value. Cement and Concrete Research 34, 1035-1041. 